\title{
Paulina Jagoda Warsza
}

\section{Irak 2018 - wybór strategiczny. Uwarunkowania i implikacje wyborów parlamentarnych w Iraku w 2018 roku}

\section{Wstęp - preludium}

W 2017 roku, 10 grudnia został ogłoszony świętem państwowym, upamiętniającym pokonanie Organizacji Państwa Islamskiego ${ }^{1}$. Wbrew przewidywaniom, iż konfrontacja z okrucieństwem tzw. Daesh usankcjonuje rozpad kraju według podziałów etnicznych, stała się ona czynnikiem jednoczącym społeczeństwo, przynajmniej te jego segmenty zaangażowane lub sympatyzujące ze społecznym ruchem protestów zapoczątkowanym w 2015 roku. Ostateczne zagrożenie państwowości wyzwoliło potencjał obywatelski pozwalający na przezwyciężenie animozji. Po 10 grudnia 2017 roku kwestie bezpieczeństwa militarnego nie dominowały już w dyskursie politycznym, ustępując miejsca potrzebom i aspiracjom społecznym.

12 maja 2018 roku odbyły się czwarte od obalenia Saddama Husajna, i pierwsze od oficjalnego ogłoszenia pokonania Daesz, wybory parlamentarne. Niespodziewanie zwyciężył Sairun (od arab. pochód, przemarsz): koalicja sadrystów Muktady as-Sadra z Iracką Partią Komunistyczną ${ }^{2}$ oraz Sojuszem Obywatelsko-Demokratycznym (zrzeszającym mniejsze ugru-

1 Organizacja ta powstała w wyniku rozłamu wewnętrznego w szeregach Al-Kaidy. Dla określenia jej obecnej nazwy używa się akronimu ISIL lub ISIS (od As-Szam, arabskiego odpowiednika Lewantu.) Sami Irakijczycy i inni Arabowie na określenie jej członków używają akronimu arabskiej nazwy-د ش - Da’asz lub Daesz.

2 Iracka Partia Komunistyczna jest najstarszą partią w Iraku, powstała w 1934 r. Chlubnie zapiała się w walce o faktyczną niezależność Iraku, wspierając rząd Karima Kasima, aby następnie stać się pierwszą ofiarą represji ze strony partii Al-Bas. Partia Komunistyczna zdobywając zaledwie dwa mandaty, w tym jeden dla kobiety w szyickim Nadżafie, powróciła po 10 latach do parlamentarnej polityki. Wiecej o irackiej Partii komunistycznej: F.A. Jabbar . The Iraqi Communist Party, [w:] Returning to Political Parties? Partisan Logic and Political Transformations in the Arab World, red. M. Catusse, K. Karam Bejrut, 2010, https://halshs.archives-ouvertes.fr/ halshs-00553955/document. 
powania). Zwycięska koalicja pozycjonowała się w kampanii wyborczej jako ugrupowanie protestu, antysystemowe i skrajnie nieinterwencjonistyczne. Jej sukces wskazuje na kontestacje przez Irakijczyków dotychczasowego porządku.

Kolejna partia, Fatah (Podbój), Hadiego al-Amiriego - przywódcy szyickich oddziałów paramilitarnych wspieranych przez Teheran, zdobyła 47 mandatów. Mimo, a może właśnie ze względu na poparcie Zachodu, premierowi Haidarowi al-Abadiemu nie udało się politycznie skapitalizować zwycięstwa nad ISIS, jego lista Nasr (Sojusz Zwycięstwa) zajęła trzecie miejsce zdobywając 42 miejsca w parlamencie.

W artykule przeprowadzono analizę wybranych czynników wpływających na wynik wyborów. W aspekcie wewnętrznym omówiono kolejno: kryzys ustrojowy związany z kurdyjskim referendum niepodległościowym, umocowanie systemowe Oddziałów Powszechnej Mobilizacji i ich przyszłą rolę w strukturach bezpieczeństwa, ewolucję masowych protestów w kierunku ruchu społecznego. Następnie przeanalizowano same wyniki wyborów i ich bezpośrednie, a także potencjalne następstwa. W kontekście międzynarodowym skupiono się na analizie zakresu irańskich możliwości oddziaływania na proces polityczny w Iraku.

Wybory te mogą stać się dla Iraku momentem przełomowym w wymiarach wewnętrznym jak i geopolitycznym, oba aspekty pozostają oczywiście we wzajemnej zależności. Analiza zaproponowana w artykule ma na celu ukazanie, iż okoliczności, przebieg i same wyniki wyborów okazały się katalizatorem rozwoju ruchu obywatelskiego, czyniąc z obywateli, bodaj po raz pierwszy, podmiot procesu wyborczego, w trakcie którego oczekiwania społeczne mogły zostać doprecyzowane i wyartykułowane. Rosnąca presja społeczna może z kolei oznaczać konieczność, ale i szansę reformy systemu politycznego, czemu sprzyjają zmiany zachodzące w otoczeniu międzynarodowym Iraku. Zmiana regionalnego układu sił oznacza renegocjacje natury relacji Bagdadu z Teheranem. Zaprezentowane przesłanki wskazują, iż zapoczątkowany został proces emancypacji politycznej mający potencjał na powrót uczynić z Iraku suwerenny podmiot polityki międzynarodowej. 


\section{Kontekst wewnętrzny}

\section{Kurdyjskie referendum niepodległościowe}

25 września 2017 roku w prowincjach Autonomicznego Regionu Kurdystanu Irackiego oraz na tzw. terytoriach spornych odbyło się referendum niepodległościowe, w którym niespełna 93 proc. głosujących odpowiedziało twierdząco na pytanie: „Czy chcesz aby Autonomiczny Region Kurdystanu Irackiego i tereny kurdyjskie poza nim ${ }^{3}$, stały się niepodległym państwem"? Frekwencja wyniosła 72 proc. ${ }^{4}$ Władze regionalne dążyły przede wszystkim do odzyskania kontroli nad roponośnym, a więc strategicznym, regionem Kirkuku odbitym przez Kurdów w trakcie ofensywy przeciw Organizacji Państwa Islamskiego i odtąd przez nich zarządzanym. Głosowanie przeprowadzono mimo braku poparcia międzynarodowego i zapowiedzi poważnych konsekwencji ze strony federalnego rządu w Bagdadzie - 12 września iracki parlament autoryzował użycie siły na spornych terenach ${ }^{5}$.

W następstwie referendum Rząd Federalny ogłosił kilkutygodniową blokadę ekonomiczną ${ }^{6}$ i lotniczą Kurdystanu ${ }^{7}$, a gospodarka regionu, jeszcze kilka lat temu przeżywająca rozkwit, pogrążyła się w recesji. Załamanie relacji Bagdadu z Irbilem oznaczało powrót do spornej kwestii alokacji budżetowych, wydawać by się mogło uregulowanej dzięki skapitalizowaniu

3 Autorom referendum chodziło o wyegzekwowanie przepisów artykułu 140 irackiej konstytucji, przewidującego zmiany podziału administracyjnego kraju na podstawie referendum wśród zainteresowanej ludności na tak zwanych terytoriach spornych.

4 Iraqi Kurds decisively back independence in referendum, https://www.bbc.com/news/ world-middle-east-41419633 [dostęp do wszystkich źródeł elektronicznych w artykule 14.09.2018].

5 A. Rasheed, R. Jalabi, Barzani vows to press on with Kurdish referendum, defying Iraq parliament, https://www.reuters.com/article/us-mideast-crisis-iraq-kurds/iraqi-parliamentrejects-kurdish-referendum-idUSKCN1BN11T?ref=hvper.com.

6 A. Rasheed, Iraq steps up retaliation against Kurdish independence vote with dollar ban, https://www.reuters.com/article/us-mideast-crisis-kurds-referendum-cenba/iraq-steps-upretaliation-against-kurdish-independence-vote-with-dollar-ban-idUSKCN1C823V.

7 R. Jalabi, Kurdistan rejects Iraq's demand to hand over airports, Baghdad readies air ban, https://www.reuters.com/article/us-mideast-crisis-kurs-referendum-airpor/kurdistanrejects-iraqs-demand-to-hand-over-airports-baghdad-readies-air-ban-idUSKCN1C20U7. 
politycznemu roli Kurdów w walce z ISIS. W 2014 roku Bagdad zgodził się przeznaczyć część środków finansowych federalnych sił Armii Irackiej dla kurdyjskiej Peszmergi w zamian za uregulowanie przepływu ropy pochodzącej ze złóż kontrolowanych przez administrację Autonomicznego Regionu Kurdystanu ${ }^{8}$. W ramach poreferendalnych retorsji politycznych zmniejszono alokacje federalnych środków budżetowych z 16 do 12,6\% ${ }^{9}$ (podczas gdy proporcjonalnie do swojego wkładu do Skarbu Państwa Kurdystan powinien otrzymywać $17 \%$ ). W wyniku ofensywy wojsk federalnych wspartych przez paramilitarne oddziały szyickie, 18 października wszystkie zdobyte przez Kurdów w trakcie walki z ISIS obszary znalazły się z powrotem pod kontrolą Bagdadu. W Kirkuku według doniesień organizacji pozarządowych dochodziło do przemocy na tle etnicznym, w przededniu ofensywy miasto opuściło około 250 tys. ludzi, głownie Kurdów i przedstawicieli innych irackich mniejszości, cześć nie wróciła.

Polityczne skutki referendum dla sprawy kurdyjskiej okazały się katastrofalne. Ujawniły się głębokie podziały wśród kurdyjskiej elity politycznej. W ostatnich latach doszło do przełamania duopolu na kurdyjskiej scenie politycznej, oddającego też podziały plemienne w regionie. Po 2005 roku stanowiska w rządzie regionalnym i administracji dzielono między dwa ugrupowania, notabene w latach dziewięćdziesiątych zaangażowane w krwawy spor wewnętrzny ${ }^{10}$ : Demokratyczną Partię Kurdystanu (DPK) skupioną wokół rodu Barzanich i Patriotyczną Unię Kurdystanu (PUK) cieszącą się patronatem Talabanich. W 2009 roku nastąpił rozłam w PUK, w wyniku którego powstał ruch Gorran, reformistyczne stronnictwo zmiany, który w 2010 roku został zarejestrowany jako partia polityczna. Począwszy od 2015 roku, iracki Kurdystan był pogrążony w kryzysie parlamentarnym, nie pozwalającym na wybór prezydenta regionu. $Z$ tego względu, w obliczu walki z ISIS, przedłużano kadencję Masouda Barzaniego. W sierpniu 2017 roku były premier regionu i jeden z liderów PUK,

8 R. Guiu, Baghdad-Erbil agreement on oil and budget: deepening Iraq's federalism?, http:// www.meri-k.org/baghdad-erbil-agreement-on-oil-and-budget-deepening-iraqs-federalism/.

9 A. Rasheed, R. Jalabi, Iraq sends money to pay Kurdish salaries for first time since 2014, https://www.reuters.com/article/us-mideast-crisis-iraq-kurds/iraq-sends-money-to-paykurdish-salaries-for-first-time-since-2014-idUSKBN1GV0T1.

10 S. Kirmanj, Identity and Nation in Iraq, Boulder 2013, https://www.rienner.com/ uploads/511e6527daedf.pdf. 
Barham Salih, typowany na przyszłego prezydenta Iraku ${ }^{11}$, założył nową partię polityczną: Koalicje dla Demokracji i Sprawiedliwości ${ }^{12}$. W tym samym czasie kurdyjski potentat medialny Shaswar Abdulwahid, założył Ruch Nowego Pokolenia ${ }^{13}$.

PUK, ruch Gorran i pozostałe partie opozycyjne oskarżyły Masouda Barzaniego, przywódcę DPK, iż forsował referendum w imię własnych ambicji politycznych, nie bacząc na konsekwencje. 29 października Masoud Barzani ogłosił ustąpienie ze stanowiska z dniem 1 listopada ${ }^{14}$, oskarżając przy tym PUK o zdradę stanu. Irański generał Kasim Sulejmani miał przekonać rodzinę zmarłego prezydenta Talabaniego, do wycofania podległych im oddziałów Peszmergi w obliczu ofensywy kirkuckiej ${ }^{15}$. Faktem jest, iż milicje szyickie zyskały znaczne wpływy w rejonie Kirkuku, co miało zwiększyć ich przewagę przed wyborami ogólnokrajowymi. Następca na stanowisku prezydenta regionu i przewodniczącego Demokratycznej Partii Kurdystanu, bratanek Masouda, Neszirwan Barzani zaakceptował orzeczenie Sądu Najwyższego z 6 listopada o niekonstytucyjności referendum $^{16}$.

Obecnie wszystkie liczące się przy tworzeniu rządu federalnego partie polityczne zabiegają o poparcie posłów z list kurdyjskich ${ }^{17}$. Może to sprzyjać deeskalacji kryzysu na linii Bagdad-Irbil. Dotychczasowy premier Al-Abadi prowadził w prowincjach kurdyjskich intensywną kampanię wyborczą ${ }^{18}$, która jednak nie odniosła sukcesu ze względu na podejmowane

11 PUK denies offering Barham Salih Iraqi presidency if he returns to party, http://www. rudaw.net/english/kurdistan/040820182.

12 Veteran Iraqi Kurdish politician announces new party, http://www.arabnews.com/ node/1173031/middle-east.

13 C. Mccaffray Van Den Toorn, Kurdistan Politics at a Crossroads, http://carnegieendowment.org/sada/76195.

14 Iraqi Kurdish leader Massoud Barzani to step down, https://www.bbc.com/news/worldmiddle-east-41794083.

15 Iran's Gen Suleimani 'issued stark warning' to Iraq Kurds over Kirkuk, https://www. thenational.ae/world/mena/iran-s-gen-suleimani-issued-stark-warning-to-iraq-kurds-overkirkuk-1.669204.

16 A. Rasheed, R. Jalabi, Iraqi court rules Kurdish independence vote unconstitutional, https://www.reuters.com/article/us-mideast-crisis-iraq-kurds/iraqi-court-rules-kurdish-independence-vote-unconstitutional-idUSKBN1DK0Q6.

17 O. Sattar, Abadi, Maliki seek alliance with Iraq's Kurds, https://www.al monitor.com/ pulse/originals/2018/07/iraq-election-government-kurdistan.html.

18 Ibidem. 
przez niego wcześniejsze decyzje wymierzone w interesy Irbilu. Przed referendum niepodległościowym szczególnie Al-Amiri i były premier Al-Maliki, politycy o inklinacjach proirańskich, prezentowali antykurdyjską postawę ${ }^{19}$; jedynie As-Sadr wypowiadał się koncyliacyjnie, nawołując przy tym do zachowania jedności kraju. Podczas ofensywy kirkuckiej spośród Oddziałów Powszechnej Mobilizacji jedynie Brygada Pokoju (Saraja As-Salem) As-Sadra, miała nie uczestniczyć w grabieży kurdyjskiego mienia i innych nadużyciach, a wręcz dążyć do deeskalacji napięć ${ }^{20}$. Czyni to z As - Sadra najmniej kontrowersyjnego partnera, dodatkowo, antysystemowe hasła sadrystów od zawsze były bliskie irackim Kurdom.

Reasumując, referendum okazało się kontrproduktywne dla sprawy kurdyjskiej. Z różnych przyczyn, takich jak: uzależnienie ekonomiczne Irbilu od Bagdadu, interesy polityczne państw ościennych, a także podziały polityczne wśród samej społeczności kurdyjskiej, należało przepuszczać, iż w interesie irackiego Kurdystanu leży niepodległość de facto, nie de iure. Wzajemne oskarżanie się partii kurdyjskich o zdradę oraz recesja gospodarcza regionu wpływają negatywnie na stabilizację sytuacji i tempo powojennej odbudowy Iraku. Konflikt Bagdadu z Irbilem, skutkujący ponowną marginalizacją kurdyjskiej Peszmergi, skutecznej w walkach z ISIS, ma negatywny wpływ na bezpieczeństwo państwa. Formacje kurdyjskie zawsze były podzielone według lojalności rodowo-plemienno-politycznych, w następstwie niejasnych okoliczności utraty Kirkuku, te rozbieżności odżyły. Wszelkie negocjacje z rządem w Bagdadzie utrudnia niezdolność Kurdów do zajęcia wspólnego stanowiska w kluczowych sprawach. Wewnątrz-kurdyjskie podziały mogą ulec dalszemu pogłębianiu przed zbliżającymi się wyborami regionalnymi we wrześniu $2018^{21}$.

\section{Siły Powszechnej Mobilizacji}

W obliczu konieczności walki z Organizacją Państwa Islamskiego, przy słabości regularnej armii irackiej, dobrym krokiem w kierunku pojednania

19 Iraq vice president warns against 'second Israel' in Kurdistan, https://www.timesofisrael. com/iraq-vice-president-warns-against-second-israel-in-kurdistan/.

20 Z.Wali, Could Kurds throw support behind a Sadr-ruled Iraq? ,http://www.rudaw.net/ english/analysis/16052018.

21 C. Mccaffray Van Den Toorn, op.cit. 
społecznego wydawała się próba włączenia bojowników plemiennych i sił paramilitarnych poszczególnych grup wyznaniowych w ofensywę przeciwko Daesz. W tym celu utworzono Siły Powszechnej Mobilizacji (powszechnie używany jest akronim nazwy ang. PMU). W założeniu miały one utworzyć struktury Gwardii Narodowej ${ }^{22}$. Z perspektywy czasu powołanie PMU okazało się nieudaną, a ze strony obozu ówczesnego premiera Al-Malikiego prawdopodobnie pozorną, próbą odzyskania państwowego monopolu przemocy. 26 listopada 2016 roku PMU zostały oficjalnie włączone w struktury armii, jako osobne odziały ${ }^{23}$, po ogłoszeniu zwycięstwa nad ISIS lojalność PMU wobec Bagdadu oraz morale pozostają kwestionowane ${ }^{24}$.

PMU zostały powołane przez ówczesnego premiera Malikiego na krótko przed utratą władzy, na mocy dekretu ${ }^{25}$. Dla ich finansowania powołano specjalną komisje i dyrektoriat podległy bezpośrednio premierowi ${ }^{26}$, co w naturalny sposób budziło oskarżenia o koncentrację władzy. Komisja odpowiedzialna za nabór partyzantów i podział funduszy obsadzona została przywódcami już działających bojówek o proweniencji irańskiej ${ }^{27}$ : Hadiego al-Amiriego, przywódcy Brygad Badr (założonych z inspiracji Teheranu podczas wojny iracko-irańskiej jako ugrupowanie dywersyjne) oraz Abu Mahdiego al-Muhandisa, lidera Kataib Hezbollah ${ }^{28}$. Wybory kadrowe jasno wskazywały na zaplecze polityczne premiera. Finanse no-

22 S. al-Salhy, Fightingfor Iraq's National Guard, http://www.aljazeera.com/news/2015/02/ fighting-iraq-national-guard-150202064153032.html .

23 Iraqi parliament passes contested law on Shi'ite paramilitaries, https://www.reuters. $\mathrm{com} /$ article/us-mideast-crisis-iraq-military/iraqi-parliament-passes-contested-law-on-shiite-paramilitaries-idUSKBN13L0IE.

24 Amnesty International oskarża cztery formacje PMU: Brygady Badr, Asaib Ahl al-Haq, Kataib Hezbollah i Saraja As-Salem (Brygady Pokoju, M. as-Sadra) o naruszenia praw człowieka, noszące znamiona zbrodni wojennych. Zbliżone wnioski formułuje Human Rights WatchZob. E, Slobe, Amnesty: Iraq militias committing war crimes, https://www.jurist.org/ news/2017/01/amnesty-iraq-militias-committing-war-crimes/.

25 R. Mansour, F. Jabar, The Popular Mobilization Forces and Iraq's Future, Carnegie Middle East Center, 28 April 2017 , http://carnegie-mec.org/2017/04/28/popular-mobilization-forces-and-iraq-s-future-pub-68810.

26 Ibidem.

27 Iraq's Popular Mobilization Units, https://fanack.com/iraq/history-past-to-present/ iraqs-popular-mobilization-units/.

28 Więcej na temat milicji szyickich w Iraku i ich przywódców w: D. Kenner, For God and Country, and Iran, https://foreignpolicy.com/2015/03/05/for-god-and-country-and-iran/. 
wego dyrektoriatu znalazły się w dużej mierze poza kontrolą budżetową parlamentu - Al-Muhandis osobiście nadzorował które odziały, a nawet poszczególni partyzanci, znajdą się na liście płac, a kto musi polegać na samofinansowaniu ${ }^{29}$. Selektywne finansowanie pozwoliło As-Sadrowi twierdzić że Brygada Pokoju, która nie otrzymuje funduszy z komisji, nie jest częścią PMU ${ }^{30}$. Premier Al-Abadi nie był w stanie przejąć kontroli nad funduszami PMU, mimo wielu zabiegów reorganizacyjnych. W lutym 2016 roku zdegradował Al-Muhandisa zastępując go emerytowanym irackim generałem Muhsinem al-Kaabim. Jednak nie pozbawiło to Al-Muhandisa faktycznego wpływu, nawet na stronach internetowych organizacji nadal widnieje on jako „lider PMU”31.

Samo powołanie PMU nie świadczy o sile wpływów irańskich w Iraku, wręcz przeciwnie, o załamaniu się dotychczasowego mechanizmu patronatu politycznego i ratowaniu go poprzez przeniesienie punktu ciężkości na aspekt bezpieczeństwa. Historycznie partia Al-Malikiego, Dawa, była jedynym ugrupowaniem szyickim w Iraku, które nie posiadało zbrojnego skrzydła, zgodnie z decyzją założyciela, Bakira As-Sadra ${ }^{32}$. Ówczesny premier zdecydował się na państwowe usankcjonowanie PMU w obawie przed utratą władzy, której i tak wkrótce został pozbawiony przy wydatnym udziale najwyższego rangą szyickiego uczonego w Iraku, uważanego za ogólnonarodowy autorytet, Wielkiego Ajatollaha Alego as-Sistaniego ${ }^{33}$.

As-Sistani zdecydował się na bezpośrednią interwencję w obliczu utraty integralności terytorialnej przez państwo w wyniku postępującej ofensywy ISIS. Wydał edykt wzywający Irakijczyków do walki w obronię ojczyzny ${ }^{34}$, do zaciągania się do państwowych instytucji, takich jak armia i policja, ale nie było w nim explicite mowy o szyizmie. Ajatollah nadal konsekwentnie odmawia użycia terminu PMU, mówi wyłącznie o ochot-

\footnotetext{
29 R.. Mansour, F. Jabar, The Popular, op.cit.

30 Ibidem.

31 Ibidem.

32 Ibidem.

33 Sistani poprzez pośrednika wygłosił kazanie, które zostało zinterpretowane jako wezwanie premiera do ustąpienia: L. Morris, A letter from Sistani turned the tide against Iraq's leader, https://www.washingtonpost.com/world/middle_east/a-letter-from-sistani-turned-the-tide-against-iraqs-leader/2014/08/13/3b3426cf-60ee-4856-ad26-d01a9c6cc9c3_story.html?utm_term $=.27 f 768$ ecb7ce.

34 R. Mansour, F. Jabar, The Popular, op.cit.
} 
nikach. Jednak koincydencja z decyzjami politycznymi Al-Malikiego spowodowała, iż słowa Ajatollaha zostały użyte do legitymizacji działań premiera. W konsekwencji pod egidą As-Sistaniego utworzono niezależne oddziały do obrony szyickich miejsc kultu w Nadżafie, Bagdadzie i Karbali ${ }^{35}$. Szybko okazało się iż brygady te, zwłaszcza Brygada Abbasa, są lepiej wyszkolone, wyposażone i zdyscyplinowane niż pozostałe $\mathrm{PMU}^{36}$ jako jedyne, na polecenie As-Sistaniego, zostały bezpośrednio włączone w struktury armii, podlegając bezpośrednio dowództwu operacyjnemu ${ }^{37}$. Brygada Abbasa, w odróżnieniu od innych PMU, została dopuszczona do bezpośredniej fazy odbicia Mosulu ${ }^{38}$.

Podsumowując, trudno jednoznacznie ocenić działalność szyickich milicji. Z perspektywy wpływu na bezpieczeństwo w Iraku, na pewno ich udział miał istotne znaczenie w walce z ISIS. Natomiast z perspektywy stabilności systemu politycznego tworzenie paralelnych, nie mających umocowania konstytucyjnego struktur militarnych, takich jak PMU wraz z ich organizacyjną nadbudową powoduje osłabianie instytucji państwa. Okoliczności powołania i struktura organizacyjna PMU, wskazują na to, iż sam premier Maliki nie miał zaufania do instytucji państwowych i wolał opierać się na tradycyjnych, poza-systemowych strukturach ${ }^{39}$. Wpisywał się tym samym w typową dla Bliskiego Wschodu antynomię rządów silnej jednostki i silnego, tj. sprawnego, państwa. Ocenę utrudnia niejednorodność PMU, w literaturze wyżnia się trzy główne frakcje o różnych inklinacjach politycznych i źródłach finansowania: proirańską, sadrystów, i oddziały wierne As-Sistaniemu ${ }^{40}$ (niemal wyłącznie finansowane przez szkołę w Nadżafie).

35 Brygady nazywano od kompleksu meczetów, za których ochronę odpowiadały Saraja al Ataba al-Abbasiya, Saraja al-Ataba al-Hussainija, Saraja al-Ataba al-Alawija, and Liwa 'Ali al-Akbar.

36 M. Knights, H. Malik, The al-Abbas Combat Division Model: Reducing Iranian Influence in Iraq's Security Forces, https://www.washingtoninstitute.org/policy-analysis/view/the-al-abbas-combat-division-model.

37 Ibidem.

38 Ibidem.

39 R. Mansour, Iraq After the Fall of ISIS: The Struggle for the State, Reaserch Paper, Middle East and North Africa Programme | July 2017, https://www.chathamhouse.org/sites/default/ files/publications/research/2017-07-04-iraq-after-isis-mansour-final.pdf.

40 R. Mansour, F. Jabar, The Popular, op.cit. 


\section{Narodziny ruchu społecznego}

Latem 2015 roku, we wszystkich większych miastach Iraku miały miejsce bezprecedensowe, kilkusettysięczne protesty pod hasłem „Prądu i bezpieczeństwa ${ }^{41}$ ". Protestujący dostrzegali zależność, sprzężenie zwrotne, między dwoma endemicznymi problemami Iraku: korupcją i przemocą. Wskazywali na związek miedzy słabością instytucji państwowych - potęgowaną przez system konsocjonalny, w którym nie tylko podział urzędów, ale i redystrybucja dochodów zachodzą w bardzo wąskich grupach - a działalnością terrorystów ${ }^{42}$, domagali się natychmiastowych reform. Bezpośrednie zagrożenie państwowości nie oznaczało już przyzwolenia na nadużycia władzy. Premier Al-Abadi, pomimo presji, nie zdecydował się na rozpędzenie demonstracji, lecz podjął bezpośrednie negocjacje ${ }^{43}$. Doszło do zmiany jakościowej, rządzący mieli być odpowiedzialni przed obywatelami.

W marcu i kwietniu 2016 roku zorganizowano wielotygodniowe antykorupcyjne protesty, połączone $\mathrm{z}$ w przeważającej mierze pokojową, okupacją dzielnicy rządowej ${ }^{44}$. Formułowane żądania, takie jak stworzenie ponadpartyjnego rządu technokratów ${ }^{45}$, świadczą o wzrastającej świadomości obywatelskiej, wykraczającej poza podziały etniczno-religijne.

Kolejne przewartościowanie zdaje się następować w fundamentalnej dla muzułmańskiego pojmowania polityki sferze - roli religii w kształtowaniu polityki. Wyznanie jako narzędzie mobilizacji politycznej, prze-

41 S. Aldouri, What to Know About Iraq's Protest Movement, https://www.chathamhouse. org/expert/comment/what-know-about-iraq-s-protest-movement.

42 National Democratic Institute (2017), Improved Security Provides Opening for Cooperation in Iraq: March to April 2017 Survey Findings', 7 June 2017, https://www.ndi.org/publications/improved-security-provides-opening-cooperation-iraq-march-april-2017-survey-findings.

43 F. Jabar, The Iraqi Protest Movement: From Identity Politics to Issue Politics, LSE Middle East Centre Paper Series |25| June 2018, http://eprints.lse.ac.uk/88294/1/Faleh_Iraqi\%20Protest\%20Movement_Published_English.pdf.

44 Tens of thousands of Iraqis protest in central Baghdad, http://www.aljazeera.com/ news/2016/04/tens-thousands-iraqis-protest-central-baghdad-160426104004117.html.

45 Iraq's parliament approves partial cabinet reshuffle, http://www.aljazeera.com/ news/2016/04/iraq-parliament-approves-partial-cabinet-reshuffle-160426180253604.html. 
stawało być skuteczne, w dotychczasowej formie ${ }^{46}$. Co ważne, przeciwko zawłaszczaniu i instrumentalizacji religii przez politykę protestowali nie tylko przedstawiciele opresjonowanych mniejszości, ale w przeważającej liczbie rządząca większość szyicka, mimo że zmiana systemu będzie oznaczać utratę przywilejów. Po 2005 roku wprowadzono w Iraku formę demokracji konsocjonalnej gwarantującej proporcjonalną tj. w założeniu sprawiedliwą, reprezentację w multietnicznych społeczeństwach. W rzeczywistości zaproponowany system kwotowego podziału stanowisk miedzy grupy etniczno-religijne (Arab. muhasasa ta'ifija) ogranicza, i tak małą na Bliskim Wschodzie, pionową mobilność społeczną. Brak możliwości awansu społecznego w szczególności dotyka młodych ludzi, którzy stanowią 60 proc. protestujących ${ }^{47}$.

Protesty uległy stopniowej instytucjonalizacji, wykształciły się kanały komunikacji, struktury lokalne i przedstawicielskie, opierające się na proaktywnym, a nie tylko reaktywnym, przeważającym w demonstracjach $\mathrm{z}$ poprzednich lat, potencjale obywateli. $\mathrm{Z}$ powszechnej frustracji narodził się ruch społeczny.

\section{Znaczenie majowych wyborów}

Wybory parlamentarne przyniosły przełom w dwóch aspektach: 1) bezpieczeństwa - po raz pierwszy nie doszło do zamachów i ataków na lokale wyborcze ${ }^{48}$, a As-Sadr po zwycięstwie nakazał całkowite rozbrojenie podległych sobie bojówek, m.in. Brygady Pokoju w prowincji Basra ${ }^{49}$; oraz 2) w aspekcie politycznym - zawarte koalicje i sojusze nie odpowiadały zasadzie kwotowego podziału stanowisk miedzy grupy etniczno-religijne ${ }^{50}$.

46 F. Jabar, The Iraqi Protest Movement, op.cit. Protestujący skandowali iż „są okradani w imię religii”. Oczywiście nie bez znaczenia były doświadczenia karykaturalnego modelu teokracji zaproponowanego przez ISIS czy lewicowo sekularystyczne inklinacje części protestujących.

47 Ibidem.

48 New Iraqi Government-unlikely-cozy-Iran, https://worldview.stratfor.com/article/ new-iraqi-government-unlikely-cozy-iran.

49 Sadr dissolves his armed brigade in south Iraq ,https://www.middleeastmonitor. com/20180628-sadr-dissolves-his-armed-brigade-in-south-iraq/.

50 F. Jabar, The Iraqi Protest Movement, op.cit. 
Przede wszystkim doszło do przetasowań wśród ugrupowań szyickich ${ }^{51}$, w tym podziału w rządzącej od 12 lat Partii Zew Islamu (Dawa). Obecny premier Al-Abadi, uznawany za umiarkowanego, wystartował przeciwko byłemu premierowi Al-Malikiemu, popieranemu przez Teheran.

Obserwatorzy zwracają uwagę na frekwencję - najniższą od 2005 roku i wynoszącą 44\% - na której miał zyskać As-Sadr. Pojawiają się ekspertyzy, iż klasa polityczna utraciła zaufanie, którym jakoby miała się cieszyć po 2003 roku. Jest to ocena dyskusyjna, dotychczasowe wyniki wyborów i frekwencję należy raczej wiązać z zależnościami klientalnymi wzmacnianymi przez system muhassasa, niż ze społecznym odbiorem klasy politycznej. $\mathrm{Na}$ frekwencję poza ewentualnym zniechęceniem wyborców niewątpliwie wpłynęły czynniki obiektywne: warunki powojenne, miliony wewnętrznych uchodźców.

Wynik wyborów, podobnie jak polityczne rozdrobnienie, wymuszają porozumienia ponad podziałami ${ }^{52}$, co stanowi pozytywny prognostyk. W obecnym składzie parlamentu 70 proc. stanowią nowi reprezentanci ${ }^{53}$ (głównie lokalni liderzy i działacze społeczni z list Sairun), z których część nie posiada doświadczenia politycznego ${ }^{54}$. Z tego względu przydatny był sojusz sadrystów z komunistami, którzy, pomimo symbolicznej reprezentacji w nowowybranym parlamencie, jako najstarsza partia w kraju o rozległych strukturach lokalnych, dysponują odpowiednim zapleczem intelektualnym i politycznym. Zwycięska koalicja nie musi kazać się efemerydą - As-Sadr utworzył wspólne listy wyborcze z partnerami z masowych protestów społecznych, na wypracowanie wspólnej linii politycznej było więc dużo czasu. Chociaż As-Sadr jest przywódcą zwycięskiej koalicji, ostentacyjnie nie kandydował do parlamentu, co w obecnym systemie uniemożliwia mu objęcie stanowiska szefa rządu. W konsekwencji Al-Abadi może utrzymać pozycję premiera ${ }^{55}$.

51 E. van Veen, N. Grinstead, F. El Kamouni-Janssen, $A$ house divided, CRU Report, February 2017, https://www.clingendael.org/sites/default/files/pdfs/a_house_divided.pdf.

52 Iraq's Future: Elections, Corruption and the Struggle for a State, oficialny transkrypt panelu eksperckiego: https://www.chathamhouse.org/event/iraq-s-future-elections-corruptionand-struggle-state.

53 Ibidem.

54 Ibidem.

55 Iraqi premier and cleric al-Sadr to form coalition, https://www.middleeastmonitor. com/20180624-iraqi-premier-and-cleric-al-sadr-to-form-coalition/. 
Dalekosiężne konsekwencje kryzysu kurdyjskiego dały o sobie znać paraliżując proces wyborczy. Chaos administracyjny na tzw. terytoriach spornych, głownie w rejonie Kirkuku, sprzyjał oskarżeniom o nieprawidłowości w lokalach, potęgowanym przez wdrożenie elektronicznego systemu liczenia głosów ${ }^{56}$. Wysoka Komisja Wyborcza zadecydowała o ręcznym przeliczaniu głosów w części okręgów ${ }^{57}$, wstrzymało to zatwierdzenie wyników wyborów przez Sad Najwyższy.

Początkowo As-Sadr zawarł wstępne porozumienia ze stronnictwami sunnickimi, negocjował też z partiami kurdyjskimi ${ }^{58}$. Zapowiadał wielką koalicję przeciwko byłemu premierowi Nuriemu al-Malikiemu, który, jeszcze przed wyborami, podsycał obecne w społeczeństwie nastroje rewolucyjne i otwarcie ostrzegał przed wojną domową ${ }^{59}$. Pierwotnie AsSadr odrzucił możliwość sojuszu z zależnymi od Teheranu PMU, obecnie jednak, dążąc do marginalizacji Al-Malikiego, rozważa taką możliwośćco Rozmowy z przywódcą religijnej milicji, Al-Amirim, stanowią bardziej ideologiczno-wizerunkowy niż polityczny problem dla koalicjantów AsSadra z Partii Komunistycznej ${ }^{61}$.

Impas w tworzeniu rządu wywołał niezadowolenie społeczne, co zostało wykorzystane przez państwa ościenne kontestujące wynik wyborów. Na przełomie czerwca i lipca, Iran zdecydował o przerwaniu dostaw prądu do rejonu Basry, oficjalnie z powodu milionowych zaległości w płatnościach ${ }^{62}$. Ponadto, dalsze zapełnianie przez Turcję zbiornika tamy Ilisu

56 B.K. Suri, Democracy has taken a leap forward in Iraq, https://www.middleeastmonitor. com/20180516-democracy-has-taken-a-leap-forward-in-iraq/.

57 M. Mostafa, Iraq cancels parliament election results at more than 1000 stations, https:// www.iraqinews.com/baghdad-politics/iraq-cancels-parliament-election-results-at-morethan-1000-stations.

58 PUK ready for negotiations with Kurdish parties, Sadr, http://www.rudaw.net/english/ kurdistan/190520182.

59 Nouri al-Maliki promises Iraq of civil war if he loses elections, http://www.thebaghdadpost.com/en/story/27151/Nouri-al-Maliki-promises-Iraq-of-civil-war-if-he-loses-elections.

60 Iraq: With a New Alliance, Sairoon and Fatah Inch Toward a Parliamentary Majority, https://worldview.stratfor.com/article/iraq-new-alliance-sairoon--fatah-inch-toward-parliamentary-majority.

61 M. Saadoun, Will Iraqi communists stick with Sadr's Sairoon Alliance?,Sadr dissolves his armed brigade in south Iraq, https://www.middleeastmonitor.com/20180628-sadr-dissolves-his-armed-brigade-in-south-iraq/ .

62 Iran cuts electricity supplies to Iraq over unpaid bills, https://www.middleeastmonitor. com/20180707-iran-cuts-electricity-supplies-to-iraq-over-unpaid-bills/. 
spowodowało obniżenie poziomu wód w rzekach, prowadząc do przedłużającej się suszy ${ }^{63}$. Irakijczycy odebrali obydwa te incydenty jako odwet za niesatysfakcjonujące sąsiadów wyniki wyborów. Czynniki te doprowadziły do gwałtownych protestów na południu kraju (w rejonach przeważnie szyickich) - niepokoje wybuchły najpierw w Basrze ${ }^{64}$, a następnie w kolejnych prowincjach Iraku min. w Nadżafie. Potępiono niewydolność państwa i obce wpływy, podpalano siedziby partii, atakowano zagraniczne spółki naftowe ${ }^{65}$. Prezydent kraju Faud Masum i Ajatollah As-Sistani ${ }^{66}$ uznali roszczenia protestujących za uzasadnione, wezwali jednak do spokoju i nieniszczenia mienia. Wybuch protestów stawia As-Sadra w trudnej sytuacji: wizerunek irackiego nacjonalisty mógł on zbudować m.in. dzięki przewodzeniu fali protestów pod bliźniaczymi do aktualnych hasłami. W konsekwencji As-Sadr zdecydował się na zawieszenie negocjacji koalicyjnych „w uznaniu roszczeń protestujących" ${ }^{\prime 67}$. Premier Al-Abadi walczący o reelekcję, przyleciał do Basry bezpośrednio ze szczytu NATO 12 lipca, na negocjacje (niestety jak się okazało nieskuteczne) ze starszyzną plemienną, domagającą się jego osobistego stawiennictwa ${ }^{68}$. Do kilku prowincji wysłano komisje rządowe, które opracowały plany reform, w tym samym czasie podejmowano jednak decyzje o mobilizacji wojska, a nawet sił antyterrorystycznych ${ }^{69}$. 27 lipca ajatollah As-Sistani wezwał siły polityczne do odpowiedzialności za kraj i jak najszybszego tworzenia rządu $^{70}$, którego główną misją powinna być „wojna przeciwko endemicznej korupcji w kraju”. Słowa te odebrano jako

63 Iraq's Water Crisis Gives the Public One More Reason to Protest, https://worldview.stratfor.com/article/iraqs-water-crisis-gives-public-one-more-reason-protest.

64 Iraqi politicians pay lip-service to anti-corruption protests, http://eu-iraq.org/index. $\mathrm{php} /$ news/item/1064-iraqi-politicians-pay-lip-service-to-anti-corruption-protests.

65 A. Mamouri, Oil installations hit by protests in southern Iraq ,http://www.al-monitor. com/pulse/originals/2018/07/iraq-basra-oilfield-protests.html\#ixzz5LPPtZdCe.

66 A. Mohammed, Iraq protests spread to Najaf in fifth day of unrest over services, corruption, https://www.reuters.com/article/us-iraq-protests-port/iraq-protests-spread-to-najaf-infifth-day-of-unrest-over-services-corruption-idUSKBN1K31OP.

67 Cleric Sadr backs Iraq protests, calls for delay in government formation, https://www. reuters.com/article/us-iraq-protests/cleric-sadr-backs-iraq-protests-calls-for-delay-in-government-formation-idUSKBN1K91U8.

68 A. Mamouri, Oil..., op.cit.

69 Iraq: Security Forces on High Alert as Protests Continue, https://worldview.stratfor.com/ situation-report/iraq-security-forces-high-alert-protests-continue.

70 A. Mohammed, Iraq..., op.cit 
wyrażające brak poparcia dla reelekcji Al-Abadiego, którego administracja nie jest w stanie odpowiedzieć na potrzeby społeczne ${ }^{71}$. Stawia to dotychczasowego premiera w niezwykle trudnym położeniu, w przeciwnym razie społeczność najwyższych w hierarchii uczonych szyickich (marjaija) będzie zmuszona oficjalnie poprzeć protestujących. Wbrew oczekiwaniom oświadczenie to nie przyniosło zdecydowanego przełomu.

Niektórzy komentatorzy oceniali antyariańskie nastawienie As-Sadra tylko jako krótkotrwałą strategię przedwyborczą, co nie znalazło dotąd odzwierciedlenia w decyzjach podejmowanych przez lidera Sairun po wyborach. Czołowy doradca Najwyższego Przywódcy Islamskiej Republiki Iranu (wrogiej wobec As-Sadra), Ali Akbar Welajati, zapowiedział jeszcze w lutym „Nie pozwolimy liberałom i komunistom rządzić w Iraku”. Działania podejmowane przez dotychczasową administracje, takie jak zdymisjonowanie ministra elektryczności, traktowane są jako w najlepszym razie niewystarczające i spóźnione, jeśli nie fasadowe. Odwołanie oficjela, który niedawno przewodniczył delegacji rządowej zawierającej w Arabii Saudyjskiej umowy w dziedzinie energetyki, przypuszczalnie, aby zrównoważyć irańską presję, wzmacnia narrację o zewnętrznych, regionalnych inspiracjach powyborczych protestów.

\section{Kontekst regionalny}

Los irackich szyitów miał zawsze znaczenie dla Iranu, od czasu rewolucji prezentującego aspiracje panislamistyczne. W obliczu narastającego zagrożenia sunnickim fundamentalizmem (Syria, Irak), wspólnota wyznaniowa skłania władze obu krajów do współpracy w dziedzinie bezpieczeństwa. Iran, przy akceptacji Stanów Zjednoczonych, uczestniczył w ofensywie przeciwko Organizacji Państwa Islamskiego ${ }^{72}$, odgrywając decydującą rolę, zarówno na poziomie taktycznym jak i operacyjnym, w odbiciu miasta Tikrit w marcu 2015 roku oraz, w strategiczne najważniejszym, odbiciu Mosulu w lipcu 2017 roku³ . Dzięki temu zaangażowaniu ponownie zwięk-

71 Ibidem. A. Mamouri, Oil..., op.cit.

72 The rise and fall of ISIL, http://www.aljazeera.com/indepth/interactive/2015/02/risefall-isil-150212075706347.html [dostęp: 14.09.2018].

73 D. Kenner, op.cit. 
szyła się kontrola Iranu nad częścią szyickich organizacji paramilitarnych w Iraku ${ }^{74}$, co w założeniu miało doprowadzić do ugruntowania wpływów politycznych, które, zwłaszcza w pierwszych latach po obaleniu Saddama, były niezwykle daleko idące. Wśród Irakijczyków wzrasta jednak świadomość negatywnych skutków zależności krajowych instytucji od Iranu, od lat wykorzystującego słabość aparatów politycznego i bezpieczeństwa. Kandydaci jednoznacznie popierani przez Teheran (Al-Amiri, Al-Maliki) osiągnęli w tegorocznych wyborach wynik słabszy od oczekiwanego. Gotowość Al-Amiriego do zawarcia koalicji z As-Sadrem przeciwko Al-Malikiemu dowodzi, że ugrupowania polityczne (czy nawet paramilitarne) wspierane przez Iran w regionie, choć często powstały z inspiracji Teheranu, tylko do pewnego stopnia działają zgodnie z jego interesami.

Dla Islamskiej Republiki Iranu polityczna emancypacja irackich szyitów oznaczała zarówno potencjalne wpływy jak i konieczność rywalizacji o ideową supremację w świecie szyickiego islamu. Fundament irańskiej rewolucji, czyli koncepcja rządów najwyższego muzułmańskiego jurysty (pers. Welajat-e Faghih $)^{75}$, był od momentu jego sformułowania obiektem polemik mudżdahidów - uczonych i przywódców religijnych z ośrodka w Nadżafie. Duchowym ojcem dużej części szyickiego establishmentu w Iraku pozostawał Wielki Ajatollah Abu Kasim al-Choi ${ }^{76}$, antagonista Chomeiniego. W konsekwencji w Iraku wykrystalizował się odmienny model postulowanego systemu państwowego. Wielki Ajatollah As-Sistani, naczelnej koncepcji irańskiej rewolucji Welajat - e-Faghih, przeciwstawia model Nizam al-Mujtama, w którym islam stanowi podstawę wartości i porządku społecznego ${ }^{77}$. AsSistani, za swoim mentorem Al-Choim, stanowczo sprzeciwia się bezpośredniej ingerencji hierarchów szyickich w politykę. Wbrew oczekiwaniom społecznym, niezwykle rzadko wprost komentuje on aktualne wydarzenia, dlatego bywa określany zwolennikiem „szkoły milczenia” (arab. al-hawza $a l$-samita ${ }^{78}$ ). Także wewnątrziracki interpelant As-Sistaniego, M. Bakir as-

74 Ibidem.

75 Irańska koncepcja rządów najwyższego jurysty szyickiego pod nieobecność, ostatniego, dwunastego imama, Mahdiego, znajdującego się w tzw. wielkim ukryciu. Zob więcej w N. Keddie, Wspótczesny Iran, Kraków 2007, s. 202- 235.

76 M. Dziekan, Irak. Religia i Polityka, Warszawa 2007, s.120.

77 Vali Nasr, The Shia Revival, New York 2007, s. 120.

78 R. Mansour, Iraq After the Fall, op.cit. 
Sadr - twórca i ideolog związanej przecież z Teheranem partii Dawa (Zew Islamu), zaproponował własny model: rządy wspólnoty (Arab. welajat al-umma $)^{79}$. Element autorytatywnych rządów jednostki, choćby wybitnej, wydaje się być przez irackich szyitów odrzucany na gruncie zarówno teologicznym jak i społecznym, co pokazują wydarzenia ostatnich lat. Aspektem odróżniającym oba ośrodki szyizmu jest też model finansowania wpływający na zależność uczonych od państwa i jego polityki ${ }^{80}$. W Iranie jest to zależność całkowita, choć obustronna, uznani uczeni stanowią element systemu i kreują politykę. W Iraku utrzymują oni siebie i instytucje dzięki sformalizowanemu systemowi datków wiernych ${ }^{81}$.

Nawoływanie dostojników szyickich do stworzenia państwa „cywilnego", obywatelskiego, może się wydawać paradoksem, odpowiedzią na aktualną sytuacje w Iraku. W istocie jednak jest kontynuacją wielopokoleniowej dysputy filozoficzno-prawnej o naturze relacji w triadzie państwo-religia-społeczeństwo. Poszanowanie porządku prawnego i instytucji państwowych to stały wątek kazań As-Sistaniego. Uczony często odwołuje się do nacjonalizmu irackiego, który jego zdaniem powinien przewyższać wszystkie inne lojalności. Ajatollah dezawuuje w ten sposób teorie o szyitach jako emisariuszach Iranu, jego zdaniem lojalność wobec ojczyzny stanowi obowiązek. As-Sistani znany jest z dystansowania się od wszelkich obcych wpływów, czemu daje wyraz demonstracyjnie odmawiając spotkań z poplecznikami Teheranu, jak Hassan Nasrallah ${ }^{82}$. W 2017 roku odmówił przyjęcia oficjalnego wysłannika Chomeiniego Mahmouda Hashemiego Szahroudi ${ }^{83}$, pomimo jego irackiego obywatelstwa. Można spotkać się z określeniem opcji ideowej reprezentowanej przez As-Sistaniego mianem „sekularnego szyizmu” ${ }^{84}$, takie określenie, to po prostu oksymoron, lepiej istotę ideologicznych podziałów w szyizmie oddaje

79 Ibidem.

80 A. Mamouri, Khamenei, Sistani, and the fight for the soul of Shiite Islam, http:// www.al-monitor.com/pulse/originals/2018/04/dueling-ayatollahs-sistani-khamenei-shiite-iran-iraq.html\#ixzz5MewGyQX8 [dostęp: 14.09.2018].

81 M. Dziekan, op.cit, s .42 i n.

82 A. Mamouri, Khamenei..., op.cit.

83 S, Hameed, Sistani refuses to meet Khamenei's envoy, http://english.alarabiya.net/en/ News/middle-east/2017/09/04/-Sistani-refuses-to-meet-Khamenei-s-envoy.html [dostęp: 14.09.2018].

84 A. Mamouri, Khamenei..., op.cit. 
rozróżnienie zaproponowane przez M. Dziekana, na szyizm polityczny i teologiczny (postulowany przez As-Sistaniego) ${ }^{85}$.

Wykształcony w Iranie As-Sadr w ostatnich latach wykonał woltę ideologiczną odwiedzając Arabię Saudyjską pierwszy raz od 11 lat. Bezprecedensowe tournée As-Sadra po sunnickich państwach Zatoki zbiegło się w czasie z wysiłkami rządu na rzecz ożywienia stosunków z arabskimi sąsiadami Ira$\mathrm{ku}^{86}$. We wrześniu 2017 roku, Al-Abadi potwierdził plany ponownego otwarcia przejścia granicznego w Arar z Arabią Saudyjską, zamkniętego od czasów wojny z Kuwejtem, a także potwierdził zgodę ma otwarcie saudyjskich konsulatów w Basrze i Nadżafie (rejonach tradycyjnie szyickich). Także sunnickie państwa Zatoki zmierzają do odzyskania wpływów w Iraku ${ }^{87}$, niegdyś orędownika jedności arabskiej. Wielki potencjał ekonomiczny regionalnych monarchii może znacznie przyspieszyć odbudowę Iraku, zwłaszcza regionów sunnickich, gdzie pomoc Teheranu jest problematyczna.

Emancypacji politycznej Iraku sprzyja kryzys wewnątrzirański. Postulaty protestujących w obu krajach ujawniły rzeczywisty, nie tylko ideologiczno-polityczny, wymiar sporu pomiędzy modelami społeczno-politycznymi proponowanymi przez konkurencyjne ośrodki szyizmu w Nadżafie i w Kom. Walka o „rząd szyickich dusz” będzie się nasilać ${ }^{88}$ : obaj przywódcy As-Sistani i Chamanei są w podeszłym wieku, As-Sistani odmawia wskazania potencjalnego następcy, natomiast sukcesja po Chamaneim będzie problematyczna, gdyż irańscy mudżdahidowie nie posiadają odpowiednich kwalifikacji teologicznych. Już wybór obecnego Najwyższego Przywódcy Islamskiej Republiki Iranu był merytorycznie dyskusyjny ${ }^{89}$, o czym lubią przypominać przeciwnicy reżimu, na szali jest wiec przetrwanie obecnego modelu państwa.

85 M. Dziekan, op.cit., s. 43.

86 Iraq will use Middle East geopolitics for gain, https://dailybrief.oxan.com/Analysis/ DB224319.

87 The Saudis may be stretching out the hand of peace to their old foes, https://www.economist.com/middle-east-and-africa/2017/09/07/the-saudis-may-be-stretching-out-the-handof-peace-to-their-old-foes.

88 A. Mamouri,Khamanei..., op.cit.

89 Shocking Video Clip From 1989 Shows Khamenei Elected Only For One Year As A Caretaker, https://en.radiofarda.com/a/video-showing-khamenei-election-supreme-leader/28963611.html. 
Jednostronne wycofanie się Stanów Zjednoczonych z Joint Comprehensive Plan Of Action ${ }^{90}$, stawia Irak w trudnej sytuacji na wielu poziomach: musi równoważyć wpływy amerykańskie i irańskie, zwłaszcza w aspektach bezpieczeństwa i gospodarki. Decyzja Waszyngtonu zmieniła dynamikę relacji regionalnych, Iran może ponownie skierować większość wysiłków w kierunku bliskiego sąsiedztwa, nie obawiając się przy tym reakcji Ameryki jako już byłego partnera. Częściowo tym można tłumaczyć zaostrzenie retoryki Teheranu wobec Bagdadu. Nowe sankcje ${ }^{91}$ nałożone na jednego z największych partnerów handlowych niewątpliwie będą miały negatywne skutki dla Iraku potrzebującego wsparcia międzynarodowego przy odbudowie terenów odbitych z rąk ISIS.

\section{Epilog}

Powtarzające się w ostatnich latach protesty ewoluujące w ruch obywatelski świadczą o zmianach w świadomości społecznej. W ich rezultacie politycy muszą przewartościować swoje postawy i zacząć odwoływać się do innych wartości niż tylko etniczne i religijne, a także zrezygnować z tradycyjnych zagranicznych patronów, lub ich nie eksponować, gdyż tego typu alianse nie gwarantują im już sukcesu na rodzimej scenie politycznej. Wymowną ilustracją stanowi zmiana postawy As-Sadra, sympatyka a następnie od 2016 roku inspiratora protestów antyrządowych, który z wychowanka Teheranu, stał się aspirującym mężem stanu, walczącym o powołanie rządu technicznego, co początkowo skonfliktowało go z pozostałymi politykami szyickimi, aby następnie doprowadzić do zwycięstwa. Polityczna ewolucja Muktady as-Sadra niemal symbolicznie oddaje geostrategiczne dylematy stojące przed, w przewadze szyickim, a zarazem arabskim, Irakiem. Sadr jako Arab ${ }^{92}$ stara się ukazywać iracki nacjonalizm i szyizm jako dwa wzajemnie uzupełniające się elementy tożsamości, mie-

90 Porozumienie międzynarodowe uzgadniające zasady kontroli irańskiego programu nuklearnego, zawarte 14 lipca 2015 [1] w Wiedniu.https://www.treasury.gov/resource-center/ sanctions/Programs/pages/iran.aspx.

91 Executive Order 13846 of August 6, 2018 Reimposing Certain Sanctions With Respect to Iran, https://www.treasury.gov/resource-center/sanctions/Programs/Documents/08062018_ iran_eo.pdf.

92 Więcej o pochodzeniu rodu as-Sadra w M. Dziekan, op.cit., s. 67. 
dzy którymi nie ma sprzeczności ${ }^{93}$, często wykorzystując antagonizmy persko-arabskie dla potwierdzenia swojej teorii.

W maju 2018 roku zwycięstwo wyborcze odniosła najmniej proirańska z dostępnych i realnych opcji. Iran będzie strzegł swojej strefy wpływów wszelkimi sposobami, w tym podsycając niepokoje społeczne, jednak, z uwagi na szereg zmiennych omówionych powyżej, podatność Irakijczyków na irańskie wpływy uległa ograniczeniu.

W Iraku doszło do załamania się ładu politycznego narzuconego po 2003 roku. Kwestionowane jest status quo oparte na przyjętym w 2005 roku systemie konsocjonalnym (sankcjonującym podział stanowisk miedzy grupy etniczno-religijne), jak i funkcja religii i etniczności jako głównych motywacji politycznych na Bliskim Wschodzie. Przez ostatnie lata dokonywała się zmiana jakościowa, fundamentalna dla rozwoju społeczeństwa obywatelskiego - odejście od tożsamościowej mobilizacji politycznej na rzecz mobilizacji problemowej ${ }^{94}$.

\section{Bibliografia}

Aldouri S., What to Know About Iraq's Protest Movement, https://www. chathamhouse.org/expert/comment/what-know-about-iraq-s-protest-movement.

Cleric Sadr backs Iraq protests, calls for delay in government formation, https://www.reuters.com/article/us-iraq-protests/cleric-sadr-backs-iraq-protests-calls-for-delay-in-government-formation-idUSKBN1 K91U8.

Executive Order 13846 of August 6, 2018 Reimposing Certain Sanctions With Respect to Iran, https://www.treasury.gov/resource-center/sanctions/Programs/Documents/08062018_iran_eo.pdf.

Guiu R., Baghdad-Erbil agreement on oil and budget: deepening Iraq's federalism?, http://www.meri-k.org/baghdad-erbil-agreement-on-oil-and-budget-deepening-iraqs-federalism/.

93 M. al-Rasheed,Salman meets al-Sadr: Saudi Arabia in search of an Iraqi Shia nationalist, thttp://www.middleeasteye.net/columns/salman-meets-al-sadr-saudi-arabia-search-iraqishia-arab-nationalist-1366130285.

94 F. Jabar, The Iraqi Protest Movement, op.cit. 
Hameed S., Sistani refuses to meet Khamenei's envoy, http://english.alarabiya.net/en/News/middle-east/2017/09/04/-Sistani-refuses-to-meet-Khamenei-s-envoy.html.

Iran cuts electricity supplies to Iraq over unpaid bills, https://www.middleeastmonitor.com/20180707-iran-cuts-electricity-supplies-to-iraq-over-unpaid-bills/.

Iran's Gen Suleimani 'issued stark warning' to Iraq Kurds over Kirkuk, https://www.thenational.ae/world/mena/iran-s-gen-suleimani-issuedstark-warning-to-iraq-kurds-over-kirkuk-1.669204.

Iraq vice president warns against 'second Israel' in Kurdistan, https://www. timesofisrael.com/iraq-vice-president-warns-against-second-israel-in-kurdistan/.

Iraq will use Middle East geopolitics for gain, https://dailybrief.oxan.com/ Analysis/DB224319.

Iraq: Security Forces on High Alert as Protests Continue, https://worldview. stratfor.com/situation-report/iraq-security-forces-high-alert-protests-continue.

Iraq: With a New Alliance, Sairoon and Fatah Inch Toward a Parliamentary Majority, https://worldview.stratfor.com/article/iraq-new-alliancesairoon--fatah-inch-toward-parliamentary-majority.

Iraq's Future: Elections, Corruption and the Struggle for a State, oficialny transkrypt panelu eksperckiego: https://www.chathamhouse.org/ event/iraq-s-future-elections-corruption-and-struggle-state.

Iraq's Popular Mobilization Units, https://fanack.com/iraq/history-past-to-present/iraqs-popular-mobilization-units/.

Iraqi Kurdish leader Massoud Barzani to step down, https://www.bbc. com/news/world-middle-east-41794083.

Iraqi Kurds decisively back independence in referendum.

Iraqi parliament passes contested law on Shi'ite paramilitaries, https:// www.reuters.com/article/us-mideast-crisis-iraq-military/iraqi-parliament-passes-contested-law-on-shiite-paramilitaries-idUSKBN13LOIE.

Iraqi politicians pay lip-service to anti-corruption protests, http://eu-iraq. org/index.php/news/item/1064-iraqi-politicians-pay-lip-service-to-anti-corruption-protests. 
Iraqi premier and cleric al-Sadr to form coalition, https://www.middleeastmonitor.com/20180624-iraqi-premier-and-cleric-al-sadr-to-form-coalition/.

Iraq's parliament approves partial cabinet reshuffle, http://www.aljazeera. com/news/2016/04/iraq-parliament-approves-partial-cabinet-reshuffle-160426180253604.html.

Iraq's Water Crisis Gives the Public One More Reason to Protest, https:// worldview.stratfor.com/article/iraqs-water-crisis-gives-public-one-more-reason-protest.

Jabar F., The Iraqi Protest Movement: From Identity Politics to Issue Politics, LSE Middle East Centre Paper Series |25| June 2018, http://eprints.lse. ac.uk/88294/1/Faleh_Iraqi\%20Protest\%20Movement_Published_English.pd.

Jabbar F.A., The Iraqi Communist Party, [w:] Returning to Political Parties? Partisan Logic and Political Transformations in the Arab World, red. M. Catusse, K. Karam, Bejrut, 2010.

Jalabi R., Kurdistan rejects Iraq's demand to hand over airports, Baghdad readies air ban, https://www.reuters.com/article/us-mideast-crisis-kurs-referendum-airpor/kurdistan-rejects-iraqs-demand-to-hand-over-airports-baghdad-readies-air-ban-idUSKCN1C20U7.

Keddie N., Wspótczesny Iran, Kraków 2007M. Dziekan, Irak. Religia i Polityka, Warszawa 2007, s.120.

Kenner D., For God and Country, and Iran, https://foreignpolicy.com/ 2015/03/05/for-god-and-country-and-iran/.

Kirmanj S. Identity and Nation in Iraq, Boulder 2013, https://www.rienner.com/uploads/511e6527daedf.pdf.

Knights M., Malik H. The al-Abbas Combat Division Model: Reducing Iranian Influence in Iraq's Security Forces; https://www.washingtoninstitute.org/policy-analysis/view/the-al-abbas-combat-division-model.

Mamouri A., Khamenei, Sistani, and the fight for the soul of Shiite Islam, http://www.al-monitor.com/pulse/originals/2018/04/dueling-ayatollahs-sistani-khamenei-shiite-iran-iraq.html\#ixzz5MewGyQX8.

Mamouri A., Oil installations hit by protests in southern Iraq ,http://www. al-monitor.com/pulse/originals/2018/07/iraq-basra-oilfield-protests. html\#ixzz5LPPtZdCe. 
Mansour R., Jabar F., The Popular Mobilization Forces and Iraq's Future, Carnegie Middle East Center, 28 April 2017, http://carnegie-mec. org/2017/04/28/popular-mobilization-forces-and-iraq-s-future-pub68810.

Mansour R., Iraq After the Fall of ISIS: The Struggle for the State, Reaserch Paper, Middle East and North Africa Programme | July 2017; https://www.chathamhouse.org/sites/default/files/publications/research/2017-07-04-iraq-after-isis-mansour-final.pdf.

Mccaffray, C. Van Den Toorn, Kurdistan Politics at a Crossroads, http:// carnegieendowment.org/sada/76195.

Mohammed A., Iraq protests spread to Najaf in fifth day of unrest over services, corruption, https://www.reuters.com/article/us-iraq-protests-port/iraq-protests-spread-to-najaf-in-fifth-day-of-unrest-overservices-corruption-idUSKBN1K31OP.

Morris L., A letter from Sistani turned the tide against Iraq's leader, https:// www.washingtonpost.com/world/middle_east/a-letter-from-sistani-turned-the-tide-against-iraqs-leader/2014/08/13/3b3426cf-60ee4856-ad2 d01a9c6cc9c3_story.html?utm_term=.27f768ecb7ce.

Mostafa M., Iraq cancels parliament election results at more than 1000 stations, https://www.iraqinews.com/baghdad-politics/iraq-cancels-parliament-election-results-at-more-than-1000-stations.

Nasr V., The Shia Revival, New York 2007, s. 120.

National Democratic Institute (2017), Improved Security Provides Opening for Cooperation in Iraq: March to April 2017 Survey Findings', 7 June 2017, https://www.ndi.org/publications/improved-security-provides-opening-cooperation-iraq-march-april-2017-survey-findings.

New Iraqi Government-unlikely-cozy-Iran, https://worldview.stratfor. $\mathrm{com} /$ article/new-iraqi-government-unlikely-cozy-iran.

Nouri al-Maliki promises Iraq of civil war if he loses elections, http://www. thebaghdadpost.com/en/story/27151/Nouri-al-Maliki-promises-Iraq-of-civil-war-if-he-loses-elections.

PUK denies offering Barham Salih Iraqi presidency if he returns to party, http://www.rudaw.net/english/kurdistan/040820182.

PUK ready for negotiations with Kurdish parties, Sadr, http://www.rudaw. net/english/kurdistan/190520182. 
Rasheed A., Iraq steps up retaliation against Kurdish independence vote with dollar ban, https://www.reuters.com/article/us-mideast-crisis-kurds-referendum-cenba/iraq-steps-up-retaliation-against-kurdish-independence-vote-with-dollar-ban-idUSKCN1C823V.

Rasheed A., Jalabi R., Barzani vows to press on with Kurdish referendum, defying Iraq parliament, https://www.reuters.com/article/us-mideast-crisis-iraq-kurds/iraqi-parliament-rejects-kurdish-referendum-idUSKCN1BN11T?ref=hvper.com.

Rasheed A., Jalabi R., Iraq sends money to pay Kurdish salaries for first time since 2014, https://www.reuters.com/article/us-mideast-crisis-iraq-kurds/iraq-sends-money-to-pay-kurdish-salaries-for-first-time-since-2014-idUSKBN1GV0T1.

Rasheed A., Jalabi R., Iraqi court rules Kurdish independence vote unconstitutional, https://www.reuters.com/article/us-mideast-crisis-iraq-kurds/iraqi-court-rules-kurdish-independence-vote-unconstitutional-idUSKBN1DK0Q6.

Rasheed M. al, Salman meets al-Sadr: Saudi Arabia in search of an Iraqi Shia nationalist, thttp://www.middleeasteye.net/columns/salman-meets-al-sadr-saudi-arabia-search-iraqi-shia-arab-nationalist-1366130285.

Saadoun M., Will Iraqi communists stick with Sadr's Sairoon Alliance?, Sadr dissolves his armed brigade in south Iraq, https://www.middleeastmonitor.com/20180628-sadr-dissolves-his-armed-brigade-insouth-iraq/.

Sally S., Fighting for Iraq's National Guard, http://www.aljazeera.com/ news/2015/02/fighting-iraq-national-guard-150202064153032.html

Sattar O., Abadi, Maliki seek alliance with Iraq's Kurds, https://www.al monitor.com/pulse/originals/2018/07/iraq-election-government-kurdistan.html.

Shocking Video Clip From 1989 Shows Khamenei Elected Only For One Year As A Caretaker, https://en.radiofarda.com/a/video-showing-khamenei-election-supreme-leader/28963611.html.

Slobe E., Amnesty: Iraq militias committing war crimes, https://www. jurist.org/news/2017/01/amnesty-iraq-militias-committing-war-crimes/. 
Suri B.K., Democracy has taken a leap forward in Iraq, https://www.middleeastmonitor.com/20180516-democracy-has-taken-a-leap-forward-in-iraq/.

Tens of thousands of Iraqis protest in central Baghdad, http://www.aljazeera.com/news/2016/04/tens-thousands-iraqis-protest-central-baghdad-160426104004117.html.

The rise and fall of ISIL, http://www.aljazeera.com/indepth/interactive/2015/02/rise-fall-isil-150212075706347.html.

The Saudis may be stretching out the hand of peace to their old foes, https:// www.economist.com/middle-east-and-africa/2017/09/07/the-saudis-may-be-stretching-out-the-hand-of-peace-to-their-old-foes.

van Veen E., Grinstead N., El Kamouni-Janssen F., A house divided, CRU Report, February 2017, https://www.clingendael.org/sites/default/files/pdfs/a_house_divided.pdf.

Veteran Iraqi Kurdish politician announces new party, http://www.arabnews.com/node/1173031/middle-east.

Wali Z., Could Kurds throw support behind a Sadr-ruled Iraq?, http:// www.rudaw.net/english/analysis/16052018.

\section{Iraq 2018 - a strategic choice. The background, implications and importance of Iraq's parliamentary elections of 2018}

\section{Summary}

The parliamentary elections of May 2018 may become a landmark for Iraq on both internal and geopolitical levels. This paper analyses internal and international preconditions of Iraqi parliamentary elections in the context of possible implications of the election results for the international position of Iraq and internal stability of the state. The international context is shaped by security situation in the region, the increased engagement of Saudi Arabia, American efforts to isolate Teheran and the internal situation in Iran as well as the growing rivalry between centers of Shia Islam in Najaf and Qom and the different models of socio-political organization they propose. In the internal dimension, the election results - while surprising for the establishment and the majority of observers are the outcome of many variables: the systemic crisis related to the Kurdish independence referendum, the disputable position and the future role of the Popular 
Mobilization Units in the political system and security apparatus. The increasing social pressure may require the reform of the Iraqi political system. The results of 2018 elections - as well as the dynamics and nature of popular protests unfolding since 2015 - show that the majority of Iraqis that are engaged in this new social movement demonstrate an anti-interventionist attitude and support the integrity of the state. The widespread protests indicate that the status quo based on the sectarian quota sharing system adopted in 2005 is being questioned, as well as the common notion that religion and ethnicity are the main political motivations in the Middle East. This article aims to demonstrate that due to the co-occurrence of specific processes and phenomena in the international environment and in Iraq itself (in area of civic-awareness that has resulted in creation of a social movement), a process of political emancipation has begun that may lead to reestablishment of Iraq as a sovereign entity in international politics.

Keywords: Iraq, parliamentary elections, Muqtada al-Sadr, the anti-system protests, social movement

\section{Ирак 2018 - стратегический выбор. Общая информация, послеАствия и важность парламентских выборов в 2018 гоАу}

\section{Резюме}

Темой Аанной статьи явцяется анализ внутренней и межАународной ситуации сопутствующей парламентским выборам в мае 2018 года в контексте возможных последствий результатов голосования Аля позиции Ирака на межАународной арене, а также Аля внутренней стабильности государства. Парламентские выборы в мае 2018 года могут стать переломным моментом Ала Ирака как и в геополитическом, так и во внутригосударственном контексте. МежАународный контекст состоит из слеАуюшищих элементов: ситуация безопастности в регионе, увеличение уровня вмешательства СауАовской Аравии, возврат США к политике изоляции Тегерана и внутренняя ситуация в Иране, заостряющийся спор межАу социально-политическими моделями преАлагаемыми конкурирующими центрами шиизма в НаАжафе и в Куме. Внутренних факторов, которые повлияли на неожиданные Аля политического истеблишмента результаты выборов, было Аостачно много: системный кризис связанный с Референдумом о независимости Иракского КурАистана, спорная мегитимизация Сих народной мобилизации (ХашА шааби) и их будущая роль в структурах безопастности. Нарастающее обще ственное Аавление может означать необходимость, а также шанс Аля про- 
ведения политических реформ. Результаты выборов 2018 года так же, как Аинамика и характер протестов продолжающихся с 2015 года, свидетельствуют о том, что участвующие в зарожАающемся общественном Авижении Иракцы в большинстве своём являются приверженцами интеграцьности государства и выступают против внешнего вмешательства в политику их страны. Протестующие не согласны со сложившимся в 2005 году статускво касающимся разАеления мест межАу разАичными этнорелигиозными группами (араб. muhasasa ta'ifija). Они оспаривают религиозность и этничость как главные компоненты политической мотивации на Ближнем Востоке. Целем данной статьи является попытка Аоказать, что парамлемьно с изменениями в межАународной среде, а также внутри самого Ирака (в аспекте развития общественного сознания, потвержАением чего явцяются зарожАающиеся общественные Авижения) зародился процесс политической эмансипации, которая имеет шанс вернуть суверенность Ирака как госу-Аарства на межАународной арене.

Кмючевые слова: Ирак, парламентские выборы, Муктада ас-СаАр, антиси-стемные протесты, общественные Авижения

mgr Paulina Jagoda Warsza

Wydział Nauk Politycznych i Studiów Międzynarodowych

Uniwersytet Warszawski

ul. Żurawia 4

00-503 Warszawa

e-mail:paulinawarsza@wp.pl 